DOI: 10.17805/trudy.2017.1.3

\title{
ИНФОРМАЦИОННЫЕ ТЕХНОЛОГИИ В РАЗВИТИИ МУЗЕЙНОГО МАРКЕТИНГА
}

\author{
А. Р. Клячина \\ Московский гуманитарный университет
}

Аннотация: Рассматриваются социокультурные функции музеев, формы и методы работы с посетителями. Анализируются некоторые вопросы организации музейного маркетинга.

Ключевые слова: музееведение; музейный маркетинг; информационные технологии; digital-инструменты

\section{INFORMATION TECHNOLOGIES IN THE DEVELOPMENT OF MUSEUM MARKETING}

\author{
A. R. Klyachina \\ Moscow University for the Humanities
}

Abstract: The article discusses the socio-cultural functions of museums, as well as forms and methods of work with visitors. It also examines some issues of the organization of museum marketing.

Keywords: museology; museum marketing; information technologies; digital tools

За последние четверть века в Российской Федерации выросла и окрепла сеть государственных (муниципальных) учреждений культуры (по сравнению с аналогичными показателями в РСФСР) - количество театров выросло в 1,7 раза (с 382 театров в 1990 г. до 661 театра в 2014 г.), количество музеев - в 2 раза (с 1315 музеев в 1990 г. до 2731 музея в 2014г.) (Стратегия ..., Электр. ресурс).

В последние годы отмечается рост театральных постановок, возрастание интереса к музейным экспозициям и выставкам. Достаточно вспомнить какие очереди выстраивались в 2016 г. в Третьяковскую галерею на Крымском Валу, чтобы все желающие смогли посетить выставку одного из самых популярных в России художника-мариниста И. Айвазовского.

Значимой акцией является бесплатное посещение музеев страны в один общий для всех день. Не менее интересна акция под названием «Ночь в музее». Очень важным направлением в музейном маркетинге 
является партнёрство - взаимное сотрудничество между музеями, в т. ч. зарубежными. Это способствует расширению аудитории, с его помощью происходит обмен экспозициями и знакомство посетителей с фондами музеев мира.

Главной задачей музейных учреждений является сохранение исторических материалов и популяризация знаний. Фонды музеев всегда были источниками информации об истории страны и ценностях мировой культуры. Возможности музеев в решении наиболее актуальных образовательных и воспитательных задач огромны. Благодаря музеям формируются гражданские и патриотические качества граждан.

Музеи проводят большую просветительскую работу. Как правило, это осуществляется во время экскурсий, экспозиций, выставок, организаций встреч с интересными людьми и др. Однако предоставление всей накопленной информации широким слоям населения часто бывает проблематичным. В прошлом все формы работы сводились только к взаимодействию посетителя и гида (либо музейного работника).

В современных условиях возможности получения знаний значительно расширены. Сегодня большое распространение получило виртуальное взаимодействие наряду с непосредственным диалогом с посетителем посредством информационных технологий. Для популяризации и продвижения музейного продукта существует множество различных digitalинструментов: веб-сайты; интерактивные панели и экраны; игровые консоли; компьютеры и планшеты, смартфоны, гаджеты; цифровое телевидение; мобильные приложения и др.

Веб-сайты необходимы для создания контента, т. е. наполнения медийного пространства информацией. Это могут быть статьи, видео, изображения, различные приложения, блоги и т. д. Весь контент должен быть интересным и понятным для пользователей. Когда информация будет для них полезной, то посетители заинтересуются и воспользуются. Если же контент будет малоинформативным, тогда посетитель заходить на этот сайт больше не станет. Дизайн контента должен соответствовать теме сайта, быть привлекательным, доступным понятным. На веб-сайтах можно использовать рекламные материалы. Активно используются также E-mail рассылки.

Социальные сети необходимы для привлечения внимания и расширения аудитории, для увеличения активности пользователей. Они являются эффективными как каналы распространения информации. Здесь возможны построения сообществ, необходимых для музейного продвижения, общение с пользователями. Социальные сети отличаются мобильностью - быстрым перемещением информации среди пользователей (вирусный контент). Благодаря социальным сетям есть возможность ин- 
дивидуально общаться с каждым посетителем, который может находиться за многие километры от музея.

Игровые консоли часто устраиваются в залах музея для того, чтобы посетители (особенно дети) могли с помощью игры понять то или иное историческое событие или более внимательно рассмотреть какой-то исторический продукт.

Одним из видов digital-инструментов является современное цифровое телевидение. Оно получило большое распространение, т. к. включает в себя не только передачу информации, но и возможность взаимодействия между носителем этой информации и телезрителем. Через цифровое телевидение можно, например, заказать и даже купить билет в музей или узнать об участии в акциях, проводимых музейными работниками.

Гаджеты и смартфоны представляют такие возможности, как просмотр различных видеоизображений, получая информацию далеко от основного источника этой информации. С помощью планшетов можно сфотографировать музейные экспонаты, передавая снимки в интернет и распространяя их.

Одним из digital-инструментов, которым успешно пользуются многие музеи, являются мобильные приложения. На их основе создаются музейные аудиомаршруты, которые могут использоваться как игры и как виртуальные экскурсии. Например, в Российском этнографическом музее в приложении можно рассмотреть интерьер музеев, коллекции и выставки. Некоторые приложения содержат навигаторы, в которых есть подробные карты галерей и музеев. Посетитель может сам для себя наметить маршрут, по которому он может его посетить. В навигаторы включаются записи художников, экспертов, предложения по составлению наиболее интересных маршрутов и многое другое.

Некоторые музеи, например, Русский музей в Санкт-Петербурге предлагает приложение - аудиогиды, которые помогают получить об экспонатах более подробную информацию. Московский музей на Остроженке (MAMM) использует электронные «маячки» iBeacon, они способны загружать информацию на сматрфоны посетителей, а специальное приложение - гид под названием «ТвойМАММ» даёт пояснение по экспонатам автоматически при приближении к ним (Благовещенский, 2015: Электр. ресурс).

Ещё один digital-инструмент был предложен разработчиками цифровых технологий, это QR-код, но он не получил распространения в нашей стране, т. к. для его прочтения необходимо использование дополнительных программ. 
Хорошо зарекомендовала себя digital-стратегия. Музейная digital стратегия отвечает на вопрос, как привлечь внимание широких слоёв населения к музейным ценностям через интернет.

Работать с digital-инструментами не так просто. Каждый из них имеет свои тонкости и настройки. Прежде чем использовать цифровые технологии необходимо продумать стратегию работы с ними, разработать чёткий план продвижения. Для этого необходимо решить следующие задачи: четко определить и сформулировать цель; определить целевую аудиторию (дети, подростки, студенты, иностранцы и т. д); подготовить контент-статьи, видео- и аудиоматериалы, электронные презентации и всё, что будет предлагаться на цифровых носителях; сформировать уникальные предложения (то, что должно заинтересовать посетителя). Затем можно приступать к выбору digital-инструментов.

Эффективное использование digital-инструментов зависит от ряда условий. Во-первых, для музеев очень важным является наличие опытных специалистов, которые имеют опыт создания и использования цифровых технологий. К сожалению, пока нет стандартов в области digital-стратегий, поэтому именно от этих специалистов зависит, как будут работать все её направления. Более того, пока некоторые из инструментов начнут работать и дадут положительный эффект должно пройти некоторое время.

Во-вторых, для решения намеченных целей приходится использовать сразу несколько digital-инструментов, при этом они должны меняться и совершенствоваться. Если какой-то инструмент запущен и работает, его постоянно нужно проверять, анализировать, поправлять. В-третьих, крайне сложно составить точный бюджетный план для реализации digitalстратегии, т. к. стоимость инструментов может меняться со временем.

Сохранение исторических материалов, популяризация знаний, привлечение и удержание посетителей - это главная цель деятельности любого музея. Улучшение технической и материальной оснащённости музея, привлечение посетителей с помощью digital-инструментов, постоянное их обновление, чёткий план стратегии приведут к эффективной реализации намеченных музеем планов.

\section{СПИСОК ЛИТЕРАТУРЫ}

Стратегия государственной культурной политики на период до 2030 года. Утверждена Распоряжением Правительства РФ от 29.02.2016 года № 326-p. [Электронный ресурс] // Правительство Российской Федерации. URL: http://government.ru/media/files/AsA9RAyYVAJnoBuKgH0qEJA9IxP7f2 xm.pdf (дата обращения: 12.11.2016). 
Благовещенский, А. (2015) Музей без проводов [Электронный ресурс] // Российская газета. 18 июня. URL: http://www.rg.ru/2015/06/18/mamm. html (дата обращения: 12.11.2016).

Дата поступления: 08.12.2016 г.

Клячина Анжелла Равиловна - магистрант кафедры теории рекламы и массовых коммуникаций Московского гуманитарного университета. Адрес: 111395, Россия, г. Москва, ул. Юности, д. 5. Тел.: +7 (903) 710-9139. Эл. адрес: klyachina_a@inbox.ru

Klyachina Angela Ravilovna, Graduate Student, Department of Theory of Advertising and Mass Communications, Moscow University for the Humanities. Postal address: 5 Yunosti St., Moscow, Russian Federation 111395. Tel.: +7 (903) 710-91-39.E-mail: klyachina_a@inbox.ru

\section{Для цитирования:}

Клячина А. Р. Информационные технологии в развитии музейного маркетинга [Электронный ресурс] // Научные труды Московского гуманитарного университета. 2017, № 1. URL: http://journals.mosgu.ru/trudy/article/view/394 (дата обращения: дд.мм. гг.). DOI: 10.17805/trudy.2017.1.3 